\title{
Reclassification of Gonyaulax verior (Gonyaulacales, Dinophyceae) as Sourniaea diacantha gen. et comb. nov.
}

\author{
Zhang Wei ${ }^{1}$, Li Zhun ${ }^{2}$, Mertens Kenneth ${ }^{3}$, Derrien Amelie ${ }^{3}$, Pospelova Vera 4, 5 , \\ Carbonell-Moore M. Consuelo ${ }^{6}$, Bagheri Siamak ${ }^{7}$, Matsuoka Kazumi ${ }^{8}$, Shin Hyeon $\mathrm{Ho}^{9,}{ }^{*}$, \\ Gu Haifeng 1, 10, *
}

\begin{abstract}
${ }^{1}$ Department of Marine Biology and Ecology, Third Institute of Oceanography, Ministry of Natural Resources, Xiamen, 361005, China

2 Biological Resource Center/Korean Collection for Type Cultures (KCTC), Korea Research Institute of Bioscience and Biotechnology, Jeongeup 56212, Korea

3 Station de Biologie Marine, Ifremer, LER BO, Place de la Croix, BP40537, Concarneau CEDEX F29185, France

${ }^{4}$ School of Earth and Ocean Sciences, University of Victoria, OEASB A405, P. O. Box 170016 STN CSC, Victoria, British Columbia V8W 2Y2, Canada

${ }^{5}$ Department of Earth and Environmental Sciences, University of Minnesota, 116 Church Street SE, Minneapolis, MN 55455, USA

${ }^{6}$ Department of Botany and Plant Pathology, College of Agricultural Sciences, Oregon State University, 2082 Cordley Hall, Corvallis, Oregon 97331-2902, USA

7 Inland Waters Aquaculture Research Center, Iranian Fisheries Science Institute, Agricultural Research Education and Extension Organization (AREEO), Anzali 43167-13111, Iran

8 Osaka Institute of Technology, 5-16-1, Omiya, Asahi-ku, Osaka City 535-8585, Japan

${ }^{9}$ Library of Marine Samples, Korea Institute of Ocean Science and Technology, Geoje 53201, Korea

10 Fujian Provincial Key Laboratory of Marine Ecological Conservation and Restoration, Xiamen 361005, China

* Corresponding authors : H. H. Shin, email address : gushh961121@kiost.ac.kr ; H. Gu, email address : guhaifeng@tio.org.cn
\end{abstract}

\begin{abstract}
:
Gonyaulax verior was initially described as Amylax diacantha from Belgian coastal waters a century ago but its detailed morphology needed restudy. Here, we established nine strains of $G$. verior by germinating cysts or isolating cells from localities from the European Atlantic to the Caspian Sea and the Pacific Ocean. Both cyst and thecal morphology were examined by light and scanning electron microscopy. SSU, LSU and/or ITS-5.8S rRNA gene sequences were obtained from all strains. Cells of $G$. verior have a plate formula of Po, 4', 2a, 6-7", 6C, 6S, 6"', 1p, 1'"' with an L-type ventral organisation, characterised by two either straight or curved antapical horns of variable length. Cysts of $G$. verior are oval, smooth and contain one or two yellow accumulation bodies. The maximum-likelihood and Bayesian inference analyses based on SSU and LSU rRNA gene sequences revealed two clades of G. verior, referred to as ribotypes A and B. Genetic distances based on ITS-5.8S rRNA gene sequences within the same ribotype were less than 0.06 , but greater than 0.32 between ribotypes. G. verior is reclassified as Sourniaea diacantha gen. et comb. nov., which is attributed to Lingulodiniaceae together with Pyxidinopsis, Lingulodinium and Amylax. Our results suggest that Lingulodiniaceae can be separated from Protoceratiaceae and Gonyaulacaceae
\end{abstract}


based on ventral organisation, apical complex, ventral pore and number of anterior intercalary plates. One strain of $S$. diacantha was examined for yessotoxin production by LC-MS/MS but did not produce toxin.

Keywords : Amylax diacantha, Cysts, Dinoflagellate, Gonyaulax longispina, Molecular phylogeny 


\section{INTRODUCTION}

The genus Gonyaulax Diesing was established with G. spinifera (Claparède \& J.Lachmann) Diesing as the type species (see e.g. Mertens \& Carbonell-Moore 2018). Thecal plates of Gonyaulax are often heavily reticulated, which makes their plate patterns not easy to observe. Based on scanning electron microscope (SEM) observations, the genus Gonyaulax was redefined as having the tabulation of Po, 3', 2a, 6", 6c, 4-8s, 5"', 1p, 1"'"' (Dodge 1989). In consequence, several species previously assigned to Gonyaulax have been transferred to other genera. For instance, G. polyedra F.Stein was transferred to the cyst-defined genus Lingulodinium D.Wall as L. polyedra (F.Stein) J.D.Dodge because its epithecal tabulation is 3', 3a, 6"' with a small 3' (Dürr 1979; Dodge 1989); G. buxus Balech was transferred to Amylax Meunier as A. buxus (Balech) J.D.Dodge because its epithecal tabulation is 3', 3a, 6" with a large 3' (Dodge 1989). The plate tabulation of Gonyaulax was later reinterpreted as 2pr, 4', 6", 6c, ?s, 6"', 1p, 1"'"' (Lewis et al. 1999). These authors interpreted the third apical plate as $\mathrm{Cv}$ (Taylor-Evitt notation), thus the two Kofoidean intercalary plates were designated as the third and fourth apical homologues as proposed before by Fensome et al. (1993).

Meunier (1919) described Amylax diacantha Meunier from Nieuwpoort, Belgium, which was transferred to Gonyaulax by Schiller (1937). However, as Gonyaulax diacantha was preoccupied, Sournia (1973) proposed the replacement name G. verior Sournia. G. verior was characterised by two long and straight antapical spines (Meunier 1919, as A. diacantha). Not long after Meunier's description, a species morphologically similar to G. verior was described as G. longispina M. Lebour from Plymouth Sound with two curved, thick antapical spines (Lebour 1925). According to Lebour (1925), G. longispina has a tabulation of 4', 2a, 6", 6"', 1p, 1"'"', and Dodge (1982) considered it a junior synonym of G. verior. However, Matsuoka et al. (1988) did not consider them conspecific 
after hatching smooth, oval cysts of G. verior from Perch Pond (Massachusetts, USA) and from Hakata Bay, Hiroshima Bay (Japan), and recognised the tabulation Po, 3', 2a, 6", 6c, 6s, 6"', 2'"' for G. verior. Cells of G. verior have also been found in Australian waters (Wood 1954), the southwest Atlantic Ocean (Balech 1988), the estuary of the Saint Lawrence River (Bérard-Therriault et al. 1999), Irish waters (Johnson \& Costello 2002), Tokyo Bay (Japan; Koibuchi \& Isobe 2007), Puerto Rican waters (Hernández-Becerril \& Navarro 1996), whereas cysts of G. verior were reported in Danish waters (Ellegaard et al. 1994), the Mediterranean Sea (Blanco 1989), the east coast of Russia (Orlova et al. 2004), Australian waters (Sonneman \& Hill 1997), the Atlantic USA and Japan (Matsuoka et al. 1988). Thecae reported by Sonneman \& Hill (1997) after hatching cysts from Australian waters had the same tabulation as reported by Matsuoka et al. (1988; 3', 2a). However, Zonneveld and Dale (1994) germinated oval cysts collected from Oslo Fjord (Norway) and considered G. verior as having another tabulation than the one reported by Matsuoka et al. (1988), differing in having four apical plates and two anterior intercalary plates (4', 2a). Since Oslo Fjord is closer to the type locality of G. verior, the Norwegian specimens might represent the true G. verior (Zonneveld \& Dale 1994). Whether G. verior can display these two tabulations, or whether these two tabulations belong to two different species or even genera needed reinvestigation. A molecular phylogeny of G. verior based on SSU rRNA gene sequences was reported by Saldarriaga et al. (2004), in which G. verior was not closely related with the type species of Gonyaulax, G. spinifera. An LSU rRNA gene phylogeny suggests that G. verior is closer to Amylax and Lingulodinium than Gonyaulax (Kim \& Kim 2007). Pyxidinopsis psilata (D.Wall \& B.Dale) M.J.Head is a cyst-defined species usually found in areas of low salinity, including Black Sea (Wall et al. 1973), and SW Caspian Sea (Mertens et al. 2018). Specimens identified as $P$. psilata from the Baltic Sea are 
considered phenotypic forms of Protoceratium reticulatum (Claparède \& J.Lachmann) Buetschli (Mertens et al. 2011). P. psilata is closest to G. verior in the molecular phylogeny based on SSU rRNA and LSU rRNA gene sequences (Mertens et al. 2018), but its corresponding motile stage has not been reported. To classify the systematic position of $G$. verior, we isolated single cysts or cells of G. verior from the French Atlantic, Pacific coastal regions, the Caspian Sea and established laboratory strains. Both cyst and theca morphology were examined with light microscopy (LM) and SEM in detail on selected strains. SSU, LSU and/or ITS-5.8S rRNA gene sequences were obtained for selected strains and molecular phylogeny was inferred.

\section{MATERIAL AND METHODS}

\section{Sample collection and treatment}

To isolate cysts, sediment sampling was done using an Ekman grab in coastal waters of China, South Korea, Iran, France and a Petite Ponar grab in western Canada between 2010 and 2018 (Table 1). The top $2 \mathrm{~cm}$ of sediment were sliced off and stored in the dark at $4{ }^{\circ} \mathrm{C}$ until further treatment. Approximately $5 \mathrm{~g}$ of wet sediment was mixed with $20 \mathrm{ml}$ of filtered seawater and stirred vigorously to dislodge detrital particles. The settled material was subsequently sieved through $120 \mu \mathrm{m}$ and 10 $\mu \mathrm{m}$ filters and collected into a residue. For isolation of cells, surface water samples were collected in South Korea in 2018 (Table 1). Single cysts were isolated from residues or cells from the plankton sample using a micropipette with an inverted Eclipse TS100 (Nikon, Tokyo, Japan) microscope and incubated in small containers with f/2-Si medium (Guillard \& Ryther 1962) at $20{ }^{\circ} \mathrm{C}, 90 \mu \mathrm{mol} \mathrm{m}^{-2} \mathrm{~s}^{-1}$ under a 12:12 h light:dark cycle. Surface sediment samples from Esquimalt Lagoon (British 
Columbia, Canada) were palynologically treated using the standardised method as described in Pospelova et al. (2010).

\section{Morphological study of thecate stages and cysts}

Living cells of all strains listed in Table 1 were examined and photographed using a Zeiss Axio Imager light microscope (Carl Zeiss, Göttingen, Germany) equipped with a Zeiss Axiocam HRc digital camera. Cell size was measured based on LM images. Fluorescence brightener Calcofluor white (Sigma Adrich, St. Louis, Missouri, USA) was used to stain the plates following the method of Fritz \& Triemer (1985). To observe the shape and location of the nucleus, cells were stained with 1:100,000 SYBR Green (Sigma Aldrich) for $1 \mathrm{~min}$, and photographed using a Zeiss fluorescence microscope with a Zeiss-38 filter set (excitation BP 470/40, beam splitter FT 495, emission BP $525 / 50)$.

For scanning electron microscopy, mid-exponential batch cultures of selected strains were concentrated by a Universal $320 \mathrm{R}$ centrifuge (Hettich-Zentrifugen, Tuttlingen, Germany) at $850 \mathrm{~g}$ for $10 \mathrm{~min}$ at room temperature. Cells were fixed with $2.5 \%$ glutaraldehyde for $3 \mathrm{~h}$ at $8{ }^{\circ} \mathrm{C}$, rinsed twice with Milli-Q water and post-fixed with $1 \% \mathrm{OsO}_{4}$ overnight at $8{ }^{\circ} \mathrm{C}$. The supernatant was removed, and the settled cells were transferred to a cover slip coated with poly-L-lysine (molecular weight 70,000-150,000). The cells attached to the cover slip were rinsed twice in Milli-Q water. The cover slips were then dehydrated in a graded ethanol series $(10 \%, 30 \%, 50 \%, 70 \%, 90 \%$ and $3 \times$ in 100\%, 10 min at each step), critical point dried (K850 Critical Point Dryer, Quorum/Emitech, West Sussex, UK), sputter-coated with gold, and examined with a Zeiss Sigma FE (Carl Zeiss, Oberkochen, Germany) scanning electron microscope at Xiamen University, China. Tabulation 
labeling follows the Kofoid system. The sulcal plate labeling follows Balech (1980).

For SEM of Korean strains LMBE-C5 and LIMS-PS-2720, $2 \mathrm{ml}$ of mid-exponential batch cultures were fixed with acidic Lugol's Iodine solution ( $0.1 \%$ final concentration) for three hours at room temperature, and then rinsed with sterile-filtered seawater and deionised water. After fixation, the filters were dehydrated in a graded ethanol series (10-99.9\% in eight steps) for $15 \mathrm{~min}$ at each step, and finally ethanol was replaced by isoamyl acetate for critical point drying (Spi-Dry Regular CPD, West Chester, Pennsylvania, USA) with liquid $\mathrm{CO}_{2}$. The filters were mounted on stubs, coated with platinum-palladium and examined with a field emission SEM microscope JEOL JSM 7600F.

\section{PCR amplifications and sequencing}

Single cells were isolated and washed several times with sterile distilled water. They were broken using a coverslip above and used for templates. PCR amplifications were carried out using $1 \times \mathrm{PCR}$ buffer, $50 \mu \mathrm{M}$ dNTP mixture, $0.2 \mu \mathrm{M}$ of each primer, and $1 \mathrm{U}$ of ExTaq DNA Polymerase (Takara, Tokyo, Japan) in $50 \mu \mathrm{l}$ reactions. The SSU rRNA gene was amplified using the primers of PRIMER A/PRIMER B (Medlin et al. 1988). The D1-D6 region of LSU rRNA gene was amplified using the primers D1R/28-1483R (Daugbjerg et al. 2000). ITS1-5.8S-ITS2 was amplified using ITSA/ITSB primers (Adachi et al. 1996). The thermal cycle procedure was 4 min at $94{ }^{\circ} \mathrm{C}$, followed by 30 cycles of $1 \mathrm{~min}$ at $94^{\circ} \mathrm{C}, 1 \mathrm{~min}$ at $45^{\circ} \mathrm{C}, 1 \mathrm{~min}$ at $72^{\circ} \mathrm{C}$, and final extension of 7 min at $72{ }^{\circ} \mathrm{C}$ with a Mastercycler (Eppendorf, Hamburg, Germany). The PCR product was purified using a DNA purification kit (Shengong, Shanghai, China) and sequenced directly in both directions on an ABI PRISM 3730XL (Applied Biosystems, Foster City, California, USA) following manufacturer’s instructions. 
For Korean strains, genomic DNA was extracted from $1 \mathrm{ml}$ of exponentially growing cultures. Sequences of SSU and partial LSU rRNA gene were amplified using the primer pairs SR1 and SR12b, and LSU D1R and LSU R2 (Takano \& Horiguchi 2006). The thermal cycle procedure was $95^{\circ} \mathrm{C}$ for $4 \mathrm{~min}$, followed by 35 cycles at $95^{\circ} \mathrm{C}$ for $30 \mathrm{~s}, 55^{\circ} \mathrm{C}$ for $30 \mathrm{~s}$ and $72{ }^{\circ} \mathrm{C}$ for $30 \mathrm{~s}$, and final extension at $72{ }^{\circ} \mathrm{C}$ for 5 min with a Mastercycler (Eppendorf, Hamburg, Germany). The PCR-amplified products were confirmed through 1.0\% agarose gel electrophoresis. For direct DNA sequencing, the PCR products were purified using a QIAquick PCR purification kit (Qiagen,

Valencia, CA). The DNA sequencing reactions were performed using the ABI PRISM® Big Dye ${ }^{\mathrm{TM}}$ Terminator Cycle Sequencing Ready Reaction Kit (Life Technologies Corporation, Carlsbad, California, USA). Newly obtained sequences were deposited in GenBank with accession numbers MT039422 to MT039442 and MT041622 to MT041629.

\section{Sequence alignment and phylogenetic analysis}

Newly obtained SSU (ca. 1700 bp) and LSU rRNA (ca. 1300 bp) gene sequences were incorporated into sequences of Gonyaulax species and related taxa available in GenBank. Sequences were aligned using MAFFT v7.110 (Katoh \& Standley 2013) online program

(http://mafft.cbrc.jp/alignment/server/) with default settings. Alignments were manually checked with BioEdit v7.0.5 (Hall 1999). The final alignment consisted of 1862 (SSU) and 1504 (LSU) base pairs including introduced gaps. For Bayesian inference (BI), the program jModelTest (Posada 2008) was used to select the most appropriate model of molecular evolution with Akaike Information Criterion (AIC). Bayesian reconstruction of the data matrix was performed using MrBayes 3.2 (Ronquist \& Huelsenbeck 2003) with the best-fitting substitution model (GTR+G). Four Markov 
chain Monte Carlo (MCMC) chains ran for 2,000,000 generations, sampling every 1000 generations. The first $10 \%$ of burn-in trees were discarded. A majority rule consensus tree was created in order to examine the posterior probabilities of each clade. Maximum likelihood (ML) analyses were conducted with RaxML v7.2.6 (Stamatakis 2006) on the T-REX web server (Boc et al. 2012) using the model GTR+G. Node support was assessed with 1000 bootstrap replicates.

Multiple ITS1-5.8S-ITS2 sequences of Gonyaulax species were aligned using MAFFT v7.110 (Katoh \& Standley 2013) online program (http://mafft.cbrc.jp/alignment/server/) with default settings. Completed alignments were imported into MEGA6 software (Tamura et al. 2013) so that divergence rates could be estimated using simple uncorrected pairwise (p) distance matrices.

\section{Yessotoxin analysis}

Cultures of strain LIMS-PS-2720 were grown in 200-ml Erlenmeyer flasks under standard culture conditions. At stationary phase (determined using sequential cell counts), $\sim 10^{5}$ cells were concentrated by centrifugation. Stationary phase was determined via linear regression of log-transformed cell count time series. Algal pellets for quantification of intracellular YTX were transferred to $2 \mathrm{ml}$ microcentrifuge tubes and stored at $-20{ }^{\circ} \mathrm{C}$ until analysis. YTXs extraction and analysis by LC-MS/MS followed the method described by Wang et al. (2019). The limit of quantification was $0.03 \mathrm{ng} \mathrm{ml}^{-1}$ for the YTX standard. 


\section{RESULTS}

\section{Sourniaea H.Gu, K.N.Mertens, Zhun Li \& H.H.Shin gen. nov.}

DESCRIPTION: Armored dinoflagellate with a plate formula of Po, 4', 2a, 6-7", 6C, 6S, 6"', 1p, 1"'". Smooth transparent cysts spherical to ovoid, with an apical archeopyle.

ETYMOLOGY: the genus is named in honor of Prof. Alain Sournia (1940-2018), distinguished French oceanographer and biologist who made great contributions to marine phytoplankton and who created the replacement name Gonyaulax verior for this species.

TYPE SPECIES: Sourniaea diacantha (Meunier) H.Gu, K.N.Mertens, Zhun Li \& H.H.Shin comb. nov.

Sourniaea diacantha (Meunier) H.Gu, K.N.Mertens, Zhun Li \& H.H.Shin comb. nov.

Figs $1-32$

BASIONYM: Amylax diacantha Meunier. [1919, Méms. Mus. R. Hist. Nat. Belg. 8, p. 74, 75, pl. 19, figs 33-36].

LECTOTYPE: Figure 33 of plate 19 in Meunier (1919) is designated here as the lectotype. HOMOTYPIC SYNONYMS: Gonyaulax diacantha (Meunier) J.Schiller 1937, p. 300, fig. 309a-c, nom. illeg. (non Athanassopoulos 1931); Gonyaulax verior Sournia 1973, p. 34 HETEROTYPIC SYNONYM: Gonyaulax longispina M.Lebour 1925, p. 97, pl. XIV, figs 4a-4c

\section{Morphology}

Cells had a conical epitheca and a rounded hypotheca with two straight or curved antapical horns 
1.8-11.1 $\mu \mathrm{m}$ long. Cells were $20.0-50.2 \mu \mathrm{m}$ long and $17.5-37.3 \mu \mathrm{m}$ wide excluding the antapical horns. Cells had a plate formula of Po, 4', 2a, 6-7"', 6C, 6S, 6"', 1p, 1"'", and an L-type ventral organisation. A small ventral pore was present on the intersection between 1', 2a and 4'. Plate 1a was as large as a quarter of 2a. Cells had radial chloroplasts and an elongated, curved nucleus in the left part. Cysts were oval, smooth with one or two accumulation bodies, and withstand palynological treatment. The archeopyle was apical and chasmic.

Two ribotypes (A and B) were identified in the molecular phylogenies (see below). These ribotypes A and B were morphologically indistinguishable but their average size varied among strains (Table 2). The plates were often reticulated with numerous pores, and the reticulations made plate boundaries difficult to observe.

Cells of $S$. diacantha ribotype B had a plate formula of Po, 4', 2a, 6-7", 6C, 6S, 6"', 1p, 1"'"' (Figs 1-4, 7-17). The thecae had a sexiform gonyaulacoid tabulation (sensu Fensome et al. 1993, their text-fig. 64B) with an L-type ventral organisation (sensu Fensome et al. 1993, text-figs 82A, C) and dextral torsion (sensu Fensome et al. 1993, text-fig. 83C) (Figs 1, 11). Cells had a conical epitheca and a rounded hypotheca with two prominent antapical horns which were either straight or curved (Figs $7,11,15$ ). The average antapical horn was $3.8 \mu \mathrm{m}$ long in the South Korean strain LIMS-PS-2720 compared to $8.7 \mu \mathrm{m}$ in another Korean strain LMBE-C5 (Table 2). Cells displayed strong compression in lateral view (Fig. 4). The chloroplasts were radially arranged, and the nucleus was elongated and curved, located in the left part of the cell (Fig. 5). Cysts of S. diacantha were ovate, smooth but often surrounded by mucus with one or two pronounced yellow accumulation bodies (Fig. 6). The archeopyle was an apical split.

The pore plate was oval and surrounded by raised ridges of neighboring apical plates (Figs 11, 13). 
The first apical plate (1') was five-sided, elongated and very narrow (Figs 1, 7, 14). Plates 2', 3' and 4' were five-sided, six-sided and four-sided respectively (Figs 2-4, 10-12). A small ventral pore was present at the junction of plates $1^{\prime}, 4^{\prime}$ and $2 \mathrm{a}$ (Figs 1,2). The two anterior intercalary plates were five-sided, and plate 1a was one fourth of plate 2a's size (Figs 1, 2, 4, 14). There were six or seven precingular plates of similar size except that the last plate $\left(6^{\prime \prime}\right.$ or $\left.7^{\prime \prime}\right)$ was smaller (Figs 1, 3, 10, 11, 13). Fusion of plates $5 "$ and 6" was observed in some cells (Fig. 15). The division suture left plates $2^{\prime \prime}, 2^{\prime}$ and $3^{\prime}$ on one side and plates $3^{\prime \prime}$ and $4 "$ on the other side (Fig. 12). The cingulum was situated in the equatorial part of the cell, descending with a displacement of one cingulum width (Figs 10, 17). The cingulum comprised six plates of similar size (Figs 7, 8, 10, 11).

The hypotheca comprised six postcingular plates, one posterior intercalary plate (1p) and one antapical plate $\left(1^{\prime \prime \prime \prime}\right)$. All postcingular plates were four-sided and similar in size, but plate $1^{\prime \prime \prime}$ was narrow, elongated and the smallest (Figs 9, 17). Plate 1p was elongated, located adjacent to plate Sp (Fig. 17). Plate 1"'" was five-sided and located in the middle of the hypotheca (Fig. 16).

The anterior part of the sulcus was narrow, while slightly widening posteriorly. Plate Sa was hook-shaped. The anterior left sulcal plate (Ssa) and the left posterior sulcal plate (Ssp) were of similar size. The anterior right sulcal plate (Sda) was larger than the posterior right sulcal plate (Sdp). The posterior sulcal plate (Sp) was elongated and much larger than the other sulcal plates (Fig. 17).

Cells of $S$. diacantha ribotype A shared the same morphology as ribotype B (Figs 18-22, 24-28). Cysts of S. diacantha ribotype A did not have a pronounced accumulation body (Fig. 23). Schematic drawings of $S$. diacantha are shown in Figs 29-32. 
Molecular phylogeny

When SSU rRNA gene sequences were compared, S. diacantha strain TIO666 (Concarneau Bay, France) differed from strain LH11 (Caspian Sea) at seven positions (99.58\% similarity). S. diacantha strain LMBE-C5 (South Korea) differed from LIMS-PS-2720 (South Korea) at two positions (99.88\%), from strain TIO928 (Bohai Sea) at nine positions (99.46\% similarity), from strain TIO492 (British Columbia, Canada) at 17 positions (98.99\% similarity), and from strain TIO666 at 88 positions (94.75\% similarity). Pyxidinopsis psilata strains LH2 and LH3 (KY681700) differed only at one position.

The maximum likelihood (ML) and Bayesian inference (BI) analyses based on SSU rRNA gene sequences yielded similar phylogenetic trees. The ML tree shows five well-resolved clades (Fig. 33). They corresponded to families Ceratiaceae, Protoceratiaceae, Pyrophacaceae, Gonyaulacaceae and Lingulodiniaceae. Lingulodiniaceae was monophyletic comprising of Sourniaea, Pyxidinopsis, Lingulodinium and Amylax with maximal support (ML bootstrap support: 100, BI posterior probability: 1.0). S. diacantha was monophyletic with maximal support, which formed a sister clade of Pyxidinopsis psilata with maximal support. They again formed a sister clade of Lingulodinium and Amylax with maximal support. Two clades of S. diacantha were identified, referred as ribotypes A and B. Ribotype A included strains from French Atlantic, Caspian Sea with maximal support. Ribotype B included strains from Bohai Sea, South Korea and Canadian Pacific with maximal support as well.

In regard to the LSU rRNA gene sequences, S. diacantha strains G54 (Bohai Sea, ribotype A) and GSFC01 (South China Sea) differed at three positions (99.57\% similarity). S. diacantha strains TIO665, TIO666 (Concarneau Bay, France) shared identical sequences, and differed from strain G54 
at 14 positions (97.99\% similarity), from strain LH11 (Caspian Sea) at 17 positions (97.55\% similarity). S. diacantha strains LMBE-C5 (South Korea), LIMS-PS-2720 (South Korea), TIO928 (Bohai Sea, Ribotype B) shared identical sequences and differed from TIO492 (Canadian Pacific) at nine positions (98.71\% similarity). Strain G54 differed from strain TIO928 at 103 positions (86.14\%) although they both originated from Bohai Sea. P. psilata isolates LH2, LH3, LH4 and LH27 shared nearly identical sequences, differing at one or two positions, but they differed from isolate LH30 at 44 positions (94.36\% similarity).

ML and BI analyses based on LSU rRNA gene sequences yielded similar phylogenetic trees. The ML tree is illustrated in Fig. 34 showing five well-resolved clades. They corresponded to families Ceratiaceae, Protoceratiaceae, Pyrophacaceae, Gonyaulacaceae and Lingulodiniaceae. Lingulodiniaceae was monophyletic comprising of Sourniaea, Pyxidinopsis, Lingulodinium and Amylax with maximal support. S. diacantha was monophyletic with maximal support, which formed a sister clade of $P$. psilata with maximal support. They again formed a sister clade of Lingulodinium and Amylax with maximal support. Two clades of $S$. diacantha were identified, referred as ribotypes A and B. Ribotype A included strains from French Atlantic, Caspian Sea, Bohai Sea and South China Sea with maximal support. Ribotype B included strains from Bohai Sea, South Korea and Canadian Pacific with maximal support as well.

For ITS-5.8S rRNA gene sequences comparison, S. diacantha strain TIO666 (Concarneau Bay, France, ribotype A) differed from strain LH11 (Caspian Sea) at 36 positions (93.39\% similarity) and from strain TIO928 (Bohai Sea, ribotype B) at 150 positions (72.53\% similarity). S. diacantha strains LMBE-C5, LIMS-PS-2720 (South Korea), and TIO928 shared identical sequences and differed from strain TIO492 (British Columbia, Canada) at 24 positions (95.6\%). P. psilata isolates LH2 and LH3 
shared identical sequences. Genetic distances within the same ribotype of $S$. diacantha were less than 0.06 , but greater than 0.32 between ribotypes (Table 3 ).

\section{Yessotoxins}

The strain LMBE-C5 was studied for YTXs. None of the 22 YTXs were detected in this strain of $S$. diacantha.

\section{DISCUSSION}

\section{Replacement Gonyaulax verior with Sourniaea diacantha}

Meunier (1919) showed two anterior intercalary plates in the original description of G. verior (as Amylax diacantha, his fig. 33 of pl. 19), with plate 2 a situated in the ventral area neighbouring the narrow plate 1'; however, he also depicted five apical plates and seven precingular plates in another figure (his fig. 36), without two anterior intercalary plates (Meunier 1919). This might suggest that the plate pattern of G. verior was inconsistent. Seven precingular plates were also observed in our strains LIMS-PS-2720 and G54 (Figs 13, 18), corresponding to both ribotypes A and B. This is probably due to the division of plate $5^{\prime \prime}$.

The morphology of G. longispina is very close to G. verior. The most pronounced difference lies in the shape of the antapical spines; straight antapical spines are observed in G. verior, whereas $G$. longispina has curved antapical spines (Lebour 1925). However, the shape and thickness of the antapical spines intergrades between both morphologies for G. verior in field samples of British Isles as reported by Dodge (1982) and in cultured strains from East Asia as reported here. Consequently, 
the shape of antapical spines in these two species cannot unambiguously separate them. G. longispina was considered as a synonym of G. verior by Dodge (1982) for this reason and the plate pattern was identified as 4', 2a, 6", 6"', 1p, 1"'" (Lebour 1925; Dodge 1982). This plate pattern was confirmed later from germinated cells from cysts collected in Oslo fjord (Zonneveld \& Dale 1994) and here from specimens of French Atlantic, Caspian Sea, China, South Korea and Canadian Pacific. However, Matsuoka et al. (1988) observed three apical plates from Japanese and American specimens of $G$. verior. Their epithecal tabulation might have been misinterpreted because sutures can be difficult to observe because of the heavy reticulations. Cysts of G. verior ribotype B often have one or two pronounced accumulation bodies, but those of ribotype A do not have such an accumulation body. It is not clear whether the accumulation body is a genotypic or phenotypic character.

Gonyaulax verior differs from the type species of Gonyaulax, G. spinifera, in several aspects. The plate tabulation is 4', 2a in G. verior instead of 3', 2a in G. spinifera (Mertens \& Carbonell-Moore 2018). Cysts of G. verior are smooth but cysts that have been related to the G. spinifera complex are process-bearing Spiniferites Mantell, and several other cyst-defined genera (e.g. Ellegaard et al. 2003). Cells of G. verior share identical plate patterns with Lingulodinium but the first anterior intercalary plate in Lingulodinium polyedra (F.Stein) J.D.Dodge is the third apical plate in G. verior. Moreover, cells of G. verior have two prominent antapical spines which cells of L. polyedra do not have. In addition, cysts of G. verior are smooth whereas those of Lingulodinium polyedra bear processes and display a distinct wall ornamentation. Cells of G. verior differ from Amylax in the tabulation (4', 2a versus 3', 3a) and lack a prominent apical horn (Dodge 1989). Therefore, we erect a new genus Sourniaea to incorporate G. verior. Since Amylax diacantha is the basionym of G. verior, the correct new name is Sourniaea diacantha. Whether motile cells of Pyxidinopsis psilata also have 
the same tabulation of Sourniaea remains to be determined.

\section{Systematic position of Sourniaea}

Sarjeant \& Downie (1974, p 26-27) first established a new family mainly based on cyst morphologies documented by Wall \& Dale (1968, p. 288), whom considered dinoflagellate cysts of the Lingulodinioid lineage to be characterised by possessing a precingular archeopyle and randomly arranged processes. The family Lingulodiniaceae Sarjeant \& C.Downie was defined with the following morphological features: (1) plate formula (sometimes) 3-6', 0-4a, 6", 6C, 6"', 1p, 1"'", if a tabulation was determinable, and if not was determinable in detail, a dense network of septa might be developed, (2) shape of theca variable, from almost spherical to polygonal, and (3) archeopyle precingular, formed by loss of one to five plates. They included two fossil genera Lingulodinium and Operculodinium D.Wall and one motile genus, Protoceratium Bergh in this new family (Sarjeant \& Downie 1974). Thus, the family Lingulodiniaceae was proposed on the basis of both cyst and thecal morphologies.

Fensome et al. (1993, p. 80-83) compiled the classification of modern and fossil dinoflagellates and considered the family Gonyaulacaceae Lindemann senior to the families Lingulodiniaceae, Protoceratiaceae Lindemann and many other families. Based on the orientation of the sulcus and dorsal torsion, Gonyaulacaceae was divided into three subfamilies, i.e. Gonyaulacoideae, Cribroperidinioideae and Leptodinioideae (Fensome et al. 1993). Gonyaulax is the type genus of the subfamily Gonyaulacoideae, which is characterised by an S-type ventral orientation and neutral torsion (Fensome et al. 1993), differing from Cribroperidinioideae and Leptodinioideae in that the latter have an L-type orientation of the sulcus and, respectively, a dextral (Cribroperidinioideae) and 
neutral or sinistral torsion (Leptodinioideae). Lingulodinium was characterised by an L-type orientation of the sulcus and dextral torsion (Lebour 1925), thus is classified within Cribroperidinioideae (Fensome et al. 1993). Sourniaea diacantha also has an L-type orientation of the sulcus and dextral torsion, which warrants its classification within the subfamily Cribroperidinioideae. In contrast, Amylax triacantha was attributed to Gonyaulacoideae (Fensome et al. 1993), although it shows an L-type orientation and neutral torsion (Lebour 1925; Dodge 1989). Steidinger \& Tangen (1996, p. 509) and Gómez (2005, p. 179) followed the classification of Gonyaulacaceae given by Fensome et al. (1993). Thereafter, Gómez (2012, p. 72) revised the classification of some of the extant dinoflagellates and placed the genera Lingulodinium and Amylax in what he informally called "the Family of Amylax", which he kept separate from Gonyaulacaceae. He also rearranged Protoceratium together with Ceratocorys F.Stein in Protoceratiaceae. The "Family of Amylax" of Gómez (2012) involves Amylax (A. buxus, A. triacantha (Jörgensen) Sournia, A. diacantha (=Sourniaea diacantha), A. verrucosa Rampi and Lingulodinium (L. polyedra and $L$. milneri (G.Murray \& Whitting) J.D.Dodge (= Goniodoma milneri G.Murray \& Whitting). Unfortunately, the classification proposed by Gómez (2012) did not provide any details on how the classification relates to morphological characters. Recently, Luo et al. (2020) showed that Protoceratiaceae were monophyletic and encompassed the genera Protoceratium, Ceratocorys, and Pentaplacodinium K.N.Mertens, Carbonell-Moore, Pospelova \& M.J.Head.

Molecular phylogenies based on both SSU and LSU rRNA gene sequences reveal the close relationship between Sourniaea, Lingulodinium, Pyxidinopsis and Amylax. These genera, although not yet known for Pyxidinopsis, share an L-type sulcus orientation with two or more anterior intercalary plates. A small ventral pore was observed on Lingulodinium (Kofoid 1911; Dodge 1989; 
Lewis \& Hallett 1997) and Amylax (Kofoid 1911; Koike \& Takishita 2008) although some Lingulodinium do not bear one (Balech 1988), similarly to some Amylax (Balech 1977). Since the Kofoidean intercalary plates could be considered apical homologues with a separate Q plate (Fensome et al. 1993), the plate tabulation of Sourniaea could be interpreted as 5', 0a as well. Likewise, Lingulodinium and Amylax could be interpreted as 5', 0a, which is consistent with their close phylogenetic relationship. Applying alternative systems proposed by Amorim et al. (2013), Alvarez et al. (2016), and Salgado et al. (2018) yield similar outcomes. In contrast, Protoceratium, Ceratocorys, Pentaplacodinium and Gonyaulax show a tabulation of 4', 0a following the modified Kofoidean tabulation recognising apical homologues (Fensome et al. 1993). Moreover, Gonyaulax often has an S-type sulcus and a conspicuous ventral pore between 3' (= Cv or Q) and 2a (Mertens \& Carbonell-Moore 2018). Therefore, we transfer Sourniaea, Lingulodinium, Amylax, together with the cyst-defined genus Pyxidinopsis, to the Lingulodiniaceae (Table 4). Fossil species belonging to the subfamilies Cribroperidinioideae and Leptodinioideae also have an L-type sulcus, and it is interesting to note that there is a also a small ventral pore in Cribroperidinium Neale \& Sarjeant (the type genus of Cribroperidinioideae; Gocht 1979; Helenes 1984), but it is difficult to assess whether these taxa belong to the Lingulodiniaceae or another family without a detailed morphological study.

\section{Biogeography and genetic differentiation of Sourniaea diacantha}

Sourniaea diacantha appears to have a wide geographic distribution, as it has been recorded in Belgium (Meunier 1919), Obidos Lagoon, Portugal (Silva 1962), Norway (Zonneveld \& Dale 1994), Ireland (Johnson \& Costello 2002), Denmark (Ellegaard et al. 1994), Mediterranean Sea (Blanco 1989), Japan (Matsuoka et al. 1988; Koibuchi \& Isobe 2007), east coast of Russia (Orlova et al. 
2004), Australia (Wood 1954; Sonneman \& Hill 1997), southwest Atlantic (Balech 1988), Puerto Rico (Hernández-Becerril \& Navarro 1996), Atlantic USA (Matsuoka et al. 1988), and Atlantic coast of Canada (Berard-Therriault et al. 1999). Here we extend its distribution to the Caspian Sea, Bohai Sea, South Korea, South China Sea and Canadian Pacific Ocean (Fig. S1). Moreover, two ribotypes of $S$. diacantha were identified for the first time. The finding of ribotype A close to the type locality suggest that it might correspond to the true $S$. diacantha. The genetic distances based on ITS-5.8S rRNA gene sequences between ribotypes A and B are greater than 0.3, suggesting cryptic diversity within the species. It is interesting to note that ribotype A has a much wider distribution than ribotype $\mathrm{B}$, which is restricted in the Pacific Ocean. The co-occurrence of the two ribotypes in the Bohai Sea might be attributed to human-assisted dispersal as reported previously (Hallegraeff \& Bolch 1992) as they have a cyst stage. However, sequences of $S$. diacantha are still limited, and more ribotypes and full understanding of its biogeography can be expected and will be the focus of future research.

\section{Emended description of Lingulodiniaceae (suborder Gonyaulacineae)}

An emended description of the family Lingulodiniaceae is needed due to the nomenclatural changes outlined above.

Lingulodiniaceae Sarjeant \& C.Downie 1974 emend. H.Gu, K.N.Mertens, Zhun Li \& H.H.Shin TYPE GENUS: Lingulodinium D.Wall

OTHER GENERA: Amylax, Sourniaea, Pyxidinopsis

EMENDED DESCRIPTION: Gonyaulacineans with an L-type orientation of the sulcus. Antapical outline more or less symmetrical. Six or seven precingular plates and, when present, two or more 
anterior intercalary plates. Small ventral pore may be located between 1', 2a and 4'.

\section{ACKNOWLEDGEMENTS}

Urban Tillmann is acknowledged for interesting taxonomic discussions. Two anonymous reviewers and the editor are thanked for constructive suggestions that improved the manuscript greatly.

\section{FUNDING}

This work was supported by the National Key Research and Development Program of China (2016YFE0202100), the National Natural Science Foundation of China (41676117), the KRIBB

Research Initiative Program, the Marine Biotechnology Program funded by the Ministry of Oceans and Fisheries of the Korean Government (20170431), and by KIOST (PE99623) project. Funding for collection of sediments in coastal waters of British Columbia (Canada) was provided by a Natural Sciences and Engineering Research Council of Canada (NSERC) Discovery grant to VP.

\section{REFERENCES}

Adachi M., Sako Y. \& Ishida Y. 1996. Analysis of Alexandrium (Dinophyceae) species using sequences of the 5.8S ribosomal DNA and internal transcribed spacer regions. Journal of Phycology 32: 424-432.

Amorim A., Veloso V., Rodríguez F. \& Fraga S., 2013. Life-cycle, morphology and phylogeny of species of Fragilidium Balech from west Iberia. In: Biological and geological perspectives ofdDinoflagellates. (Eds. by J. Lewis, F. Marret \& L. Bradley), pp. 215-224. The Micropaleontological Society, London, UK.

Álvarez G., Uribe E., Regueiro J., Blanco J. \& Fraga S. 2016. Gonyaulax taylorii, a new yessotoxins-producer dinoflagellate species from Chilean waters. Harmful Algae 58: 8-15. 
Athanassopoulos G. 1931. Microfaune du Golfe de Salonique, etc. Buletin de l'Institut Océanographique 588: 1-26.

Balech E. 1977. Cuatro especies de "Gonyaulax" sensu lato, y consideraciones sobre el género (Dinoflagellata). Revista Museo Argentino de Ciencias Naturales "Bernardino Rivadavia". Hidrobiología 5: 115-136.

Balech E. 1980. On the thecal morphology of dinoflagellates with special emphasis on cingular and sulcal plates. Anales del Centro de Ciencias del Mar y Limnología, Universidad Nacional Autónoma de México 7: 57-68.

Balech E. 1988. Los dinoflagellados del Atlántico sudoccidental. Publicaciones Especiales Instituto Español de Oceanografía 1: 1-310.

Bérard-Therriault L., Poulin M. \& Bossé L. 1999. Guide d'identification du phytoplancton marin de l'estuaire et du golfe du Saint-Laurent incluant également certains protozoaires. Publication spéciale canadienne des sciences halieutiques et quatiques 128. Les Presses Scientifiques du CNRC, Ottawa, Canada. 387 pp.

Blanco J. 1989. Quistes de Dinoflagelados de las costas de Galicia. I. Dinoflagelados gonyaulacoides. Scientia Marina 53: 785-796.

Boc A., Diallo A.B. \& Makarenkov V. 2012. T-REX: a web server for inferring, validating and visualizing phylogenetic trees and networks. Nucleic Acids Research 40: W573-W579.

Daugbjerg N., Hansen G., Larsen J. \& Moestrup Ø. 2000. Phylogeny of some of the major genera of dinoflagellates based on ultrastructure and partial LSU rDNA sequence data, including the erection of three new genera of unarmoured dinoflagellates. Phycologia 39: 302-317.

Dodge J.D. 1982. Marine dinoflagellates of the British Isles. Her Majesty's Stationery Office, 
London, UK. 303 pp.

Dodge J.D. 1989. Some revisions of the family Gonyaulacaceae (Dinophyceae) based on a scanning electron microscope study. Botanica Marina 32: 275-298.

Dürr G. 1979. Elektronenmikroskopische Untersuchungen am Panzer von dinoflagellaten: I.

Gonyaulax polyedra. Archiv für Protistenkunde 122: 55-87.

Ellegaard M., Christensen N.F. \& Moestrup Ø. 1994. Dinoflagellate cysts from recent Danish marine sediments. European Journal of Phycology 29: 183-194.

Ellegaard M., Daugbjerg N., Rochon A., Lewis J. \& Harding I. 2003. Morphological and LSU rDNA sequence variation within the Gonyaulax spinifera-Spiniferites group (Dinophyceae) and proposal of G. elongata comb. nov. and G. membranacea comb. nov. Phycologia 42: $151-164$.

Fensome R.A., Taylor F.J.R., Norris G., Sarjeant W.A.S., Wharton D.I. \& Williams G.L. 1993. A classification of fossil and living dinoflagellates. Micropaleontology Special Publication 7: $1-245$.

Fritz L. \& Triemer R. 1985. A rapid simple technique utilizing calcofluor white M2R for the visualization of dinoflagellate thecal plates. Journal of Phycology 21: 662-664.

Gocht H. 1979. Korrelation von Überlappungs system und Wachstum bei fossilen Dinoflagellaten (Gonyaulax-Gruppe). Neues Jahrbuch für Geologie und Paläontologie, Abhandlungen 157: $344-365$.

Gómez F. 2005. A list of free-living dinoflagellate species in the world's oceans. Acta Botanica Croatica 64: 129-212.

Gómez F. 2012. A checklist and classification of living dinoflagellates (Dinoflagellata, Alveolata). 
CICIMAR Oceánides 27: 65-140.

Guillard R.R.L. \& Ryther J.H. 1962. Studies of marine planktonic diatoms. I. Cyclotella nana Hustedt and Detonula confervacea Cleve. Canadian Journal of Microbiology 8: 229-239.

Hall T.A. 1999. BioEdit: a user-friendly biological sequence alignment editor and analysis program for Windows 95/98/NT. Nucleic Acids Symposium Series 41: 95-98.

Hallegraeff G.M. \& Bolch C. 1992. Transport of diatom and dinoflagellate resting spores in ships' ballast water: implications for plankton biogeography and aquaculture. Journal of Plankton Research 14: 1067-1084.

Helenes J. 1984. Morphological analysis of mesozoic-cenozoic Cribroperidinium (Dinophyceae), and taxonomic implications. Palynology 8: 107-137.

Hernández-Becerril D.U. \& Navarro N. 1996. Thecate dinoflagellates (Dinophyceae) from Bahía Fosforescente, Puerto Rico. Revista de Biologia Tropical 44: 465-475.

Johnson M. \& Costello M. 2002. Local and external components of the summertime plankton community in Lough Hyne, Ireland a stratified marine inlet. Journal of Plankton Research 24: 1305-1315.

Katoh K. \& Standley D.M. 2013. MAFFT multiple sequence alignment software version 7: improvements in performance and usability. Molecular Biology and Evolution 30: 772-780.

Kim K. \& Kim C. 2007. Phylogenetic relationships among diverse dinoflagellate species occurring in coastal waters off Korea inferred from large subunit ribosomal DNA sequence data. Algae 22: $57-67$.

Koibuchi Y. \& Isobe M. 2007. Phytoplankton bloom mechanism in an area affected by eutrophication: Tokyo Bay in spring 1999. Coastal Engineering Journal 49: 461-479. 
Kofoid C. A. 1911. Dinoflagellata of the San Diego region, IV. The genus Gonyaulax with notes on its skeletal morphology and a discussion of its generic and specific characters. University of California Publications in Zoology 8: 187-286.

Koike K. \& Takishita K. 2008. Anucleated cryptophyte vestiges in the gonyaulacalean dinoflagellates Amylax buxus and Amylax triacantha (Dinophyceae). Phycological Research 56: $301-311$.

Lebour M.V. 1925. The dinoflagellates of the northern seas. Marine Biological Association of the United Kingdom, Plymouth, UK. 250 pp.

Lewis J. \& Hallett R. 1997. Lingulodinium polyedrum (Gonyaulax polyedra) a blooming dinoflagellate. Oceanography and Marine Biology 35: 97-162.

Lewis J., Rochon A. \& Harding I. 1999. Preliminary observations of cyst-theca relationships in Spiniferites ramosus and Spiniferites membranaceus (Dinophyceae). Grana 38: 113-124.

Luo Z., Lim Z.F., Mertens K.N., Krock B., Teng S.T., Tan T.H., Leaw C.P., Lim P.T. \& Gu H. 2020. Attributing Ceratocorys, Pentaplacodinium and Protoceratium to Protoceratiaceae (Dinophyceae), with descriptions of Ceratocorys malayensis sp. nov. and Pentaplacodinium usupianum sp. nov. Phycologia 59: 6-23.

Matsuoka K., Fukuyo Y. \& Anderson D.M. 1988. The cyst and theca of Gonyaulax verior Sournia (Dinophyceae) and their implication for the systematics of the genus Gonyaulax. Japanese Journal of Phycology 36: 311-320.

Medlin L., Elwood H.J., Stickel S. \& Sogin M.L. 1988. The characterization of enzymatically amplified eukaryotic 16S-like rRNA-coding regions. Gene 71: 491-499.

Mertens K. N. \& Carbonell-Moore M.C. 2018. Introduction to Spiniferites Mantell 1850. Palynology 
42(supp1.): 1-9.

Mertens K.N., Dale B., Ellegaard M., Jansson I., Godhe A., Kremp A. \& Louwye S. 2011. Process length variation in cysts of the dinoflagellate Protoceratium reticulatum, from surface sediments of the Baltic-Kattegat-Skagerrak estuarine system: a regional salinity proxy. Boreas 40: 242-255.

Mertens K.N., Takano Y., Gu H., Bagheri S., Pospelova V., Pieńkowski A.J., Leroy S. \& Matsuoka K. 2018. Cyst-theca relationship and phylogenetic position of Impagidinium caspienense incubated from Caspian Sea surface sediments: Relation to Gonyaulax baltica and evidence for heterospory within Gonyaulacoid dinoflagellates. Journal of Eukaryotic Microbiology 64: $829-842$.

Meunier A. 1919. Microplankton de la Mer Flamande. III. Les Péridiniens. Le Musée royal d'histoire naturelle de Belgique, Mémoires 8: 3-116.

Orlova T.Y., Morozova T.V., Gribble K.E., Kulis D.M. \& Anderson D.M. 2004. Dinoflagellate cysts in recent marine sediments from the east coast of Russia. Botanica Marina 47: 184-201.

Posada D. 2008. jModelTest: phylogenetic model averaging. Molecular Biology and Evolution 25: $1253-1256$.

Pospelova V., Esenkulova S., Johannessen S.C., O’Brien M.C. \& MacDonald R.W. 2010. Organic-walled dinoflagellate cyst production, composition and flux from 1996 to 1998 in the central Strait of Georgia (BC, Canada): a sediment trap study. Marine Micropaleontology 75: 17-37.

Ronquist F. \& Huelsenbeck J.P. 2003. MrBayes 3: bayesian phylogenetic inference under mixed models. Bioinformatics 19: 1572-1574. 
Saldarriaga J.F., Taylor F.J.R.M., Cavalier-Smith T., Menden-Deuer S. \& Keeling P.J. 2004.

Molecular data and the evolutionary history of dinoflagellates. European Journal of Protistology 40: 85-111.

Salgado P., Fraga S., Rodríguez F., Riobó P. \& Bravo I. 2018. Ceratocorys mariaovidiorum sp. nov. (Gonyaulacales), a new dinoflagellate species previously reported as Protoceratium reticulatum. Journal of Phycology 54: 126-137.

Sarjeant W.A. \& Downie C. 1974. The classification of dinoflagellate cysts above generic level: a discussion and revisions. Birbal Sahni Institute of Palaeobotany Special Publication 3: 9-32.

Schiller J. 1937. Dinoflagellatae (Peridineae) in monographischer Behandlung. In:

Kryptogamen-Flora von Deutschland, Österreich und der Schweiz (Ed. by L. Rabenhorst), pp. 1-589. Akademische, Leipzig, Germany.

Silva De E.S. 1962. Some observations on marine dinoflagellate cultures. II. Glenodinium foliaceum Stein and Gonyulax dicantha (Meunier) Schiller. Botanica Marina 3: 75-98.

Sonneman J. \& Hill D. 1997. A taxonomic survey of cyst-producing dinoflagellates from recent sediments of Victorian coastal waters, Australia. Botanica Marina 40: 149-178.

Sournia A. 1973. Catalogue des espèces et taxons infraspécifiques de dinoflagellés marins actuels publiés depuis la révision de J. Schiller. I. Dinoflagellés libres. Beihefte zur Nova Hedwigia 48: $1-92$.

Stamatakis A. 2006. RAxML-VI-HPC: maximum likelihood-based phylogenetic analyses with thousands of taxa and mixed models. Bioinformatics 22: 2688-2690.

Steidinger K.A. \& Tangen K. 1996. Dinoflagellates. In: Identifying marine diatoms and dinoflagellates (Ed. by E.R. Tomas), pp. 387-598. Academic Press, San Diego, California, 
USA,

Takano Y. \& Horiguchi T. 2006. Acquiring scanning electron microscopical, light microscopical and multiple gene sequence data from a single dinoflagellate cell. Journal of Phycology 42: $251-256$.

Tamura K., Stecher G., Peterson D., Filipski A. \& Kumar S. 2013. MEGA6: molecular evolutionary genetics analysis version 6.0. Molecular Biology and Evolution 30: 2725-2729.

Wall D. \& Dale B. 1968. Modern dinoflagellate cysts and evolution of the Peridiniales. Micropaleontology 14: 265-304.

Wall D., Dale B. \& Harada K. 1973. Description of new fossil dinoflagellates from the Late Quaternary of the Black Sea. Micropaleontology 21: 18-31.

Wang N., Mertens K.N., Krock B., Luo Z., Derrien A., Pospelova V., Liang Y., Bilien G., Smith K.F., De Schepper S., Wietkamp S., Tillmann U. \& Gu H. 2019. Cryptic speciation in Protoceratium reticulatum (Dinophyceae): evidence from morphological, molecular and ecophysiological data. Harmful Algae 88: 101610.

Wood E.F. 1954. Dinoflagellates in the Australian region. Marine and Freshwater Research 5: $171-352$.

Zonneveld K.A.F. \& Dale B. 1994. The cyst-motile stage relationships of Protoperidinium monospinum (Paulsen) Zonneveld et Dale comb. nov. and Gonyaulax verior (Dinophyta, Dinophyceae) from the Oslo Fjord (Norway). Phycologia 33: 359-368. 


\section{Figure Captions}

Figs 1-6. Light micrographs of Sourniaea diacantha ribotype B from Esquimalt Lagoon (British Columbia, Canada). Scale bars $=10 \mu \mathrm{m}$.

Figs 1-2. Ventral view of living cells showing three apical plates $\left(1^{\prime}, 2^{\prime}, 4^{\prime}\right)$, two anterior intercalary (1a, 2a) plates, a small ventral pore (arrowhead) and two precingular plates $\left(5^{\prime \prime}, 6^{\prime \prime}\right)$.

Fig. 3. Dorsal view of a living cell showing two apical plates $\left(2^{\prime}, 3^{\prime}\right)$, three precingular plates $\left(2^{\prime \prime}-4^{\prime \prime}\right)$.

Fig. 4. A living cell in lateral view.

Fig. 5. A SYBR Green stained cell showing the nucleus.

Fig. 6. A living cyst. 


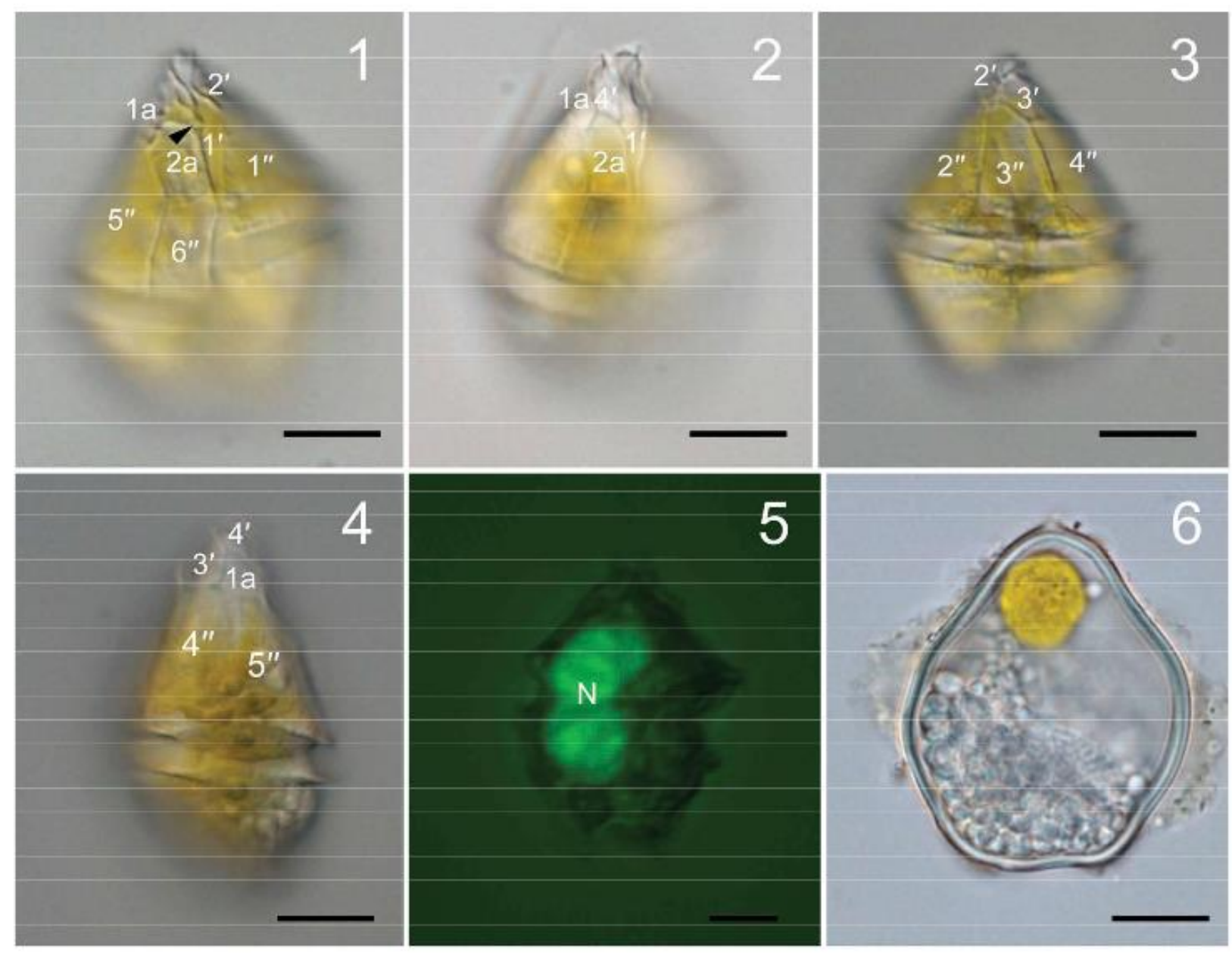

Figs 7-9. Scanning electron micrographs of Sourniaea diacantha ribotype B strain LMBE-C5 from South Korea.

Fig. 7. Ventral view showing three apical plates $\left(1^{\prime}, 2^{\prime}, 4^{\prime}\right)$, one anterior intercalary (2a) plate, three precingular plates $\left(1^{\prime \prime}, 5^{\prime \prime}, 6^{\prime \prime}\right)$. Scale bar $=10 \mu \mathrm{m}$.

Fig. 8. Dorsal view showing two precingular $\left(2^{\prime \prime}, 3^{\prime \prime}\right)$, cingular $(\mathrm{C} 3, \mathrm{C} 4)$ and postcingular $\left(4^{\prime \prime \prime}, 5^{\prime \prime \prime}\right)$ plates. Scale bar $=10 \mu \mathrm{m}$.

Fig. 9. Internal view of the sulcus showing the first two postcingular plates $\left(1^{\prime \prime \prime}, 2^{\prime \prime \prime}\right)$, the anterior sulcal plate (Sa), anterior left sulcal plate (Ssa), anterior right sulcal plate (Sda), posterior left sulcal plate (Ssp), posterior right sulcal plate (Sdp) and posterior sulcal plate (Sp). Scale bar $=5 \mu \mathrm{m}$. 

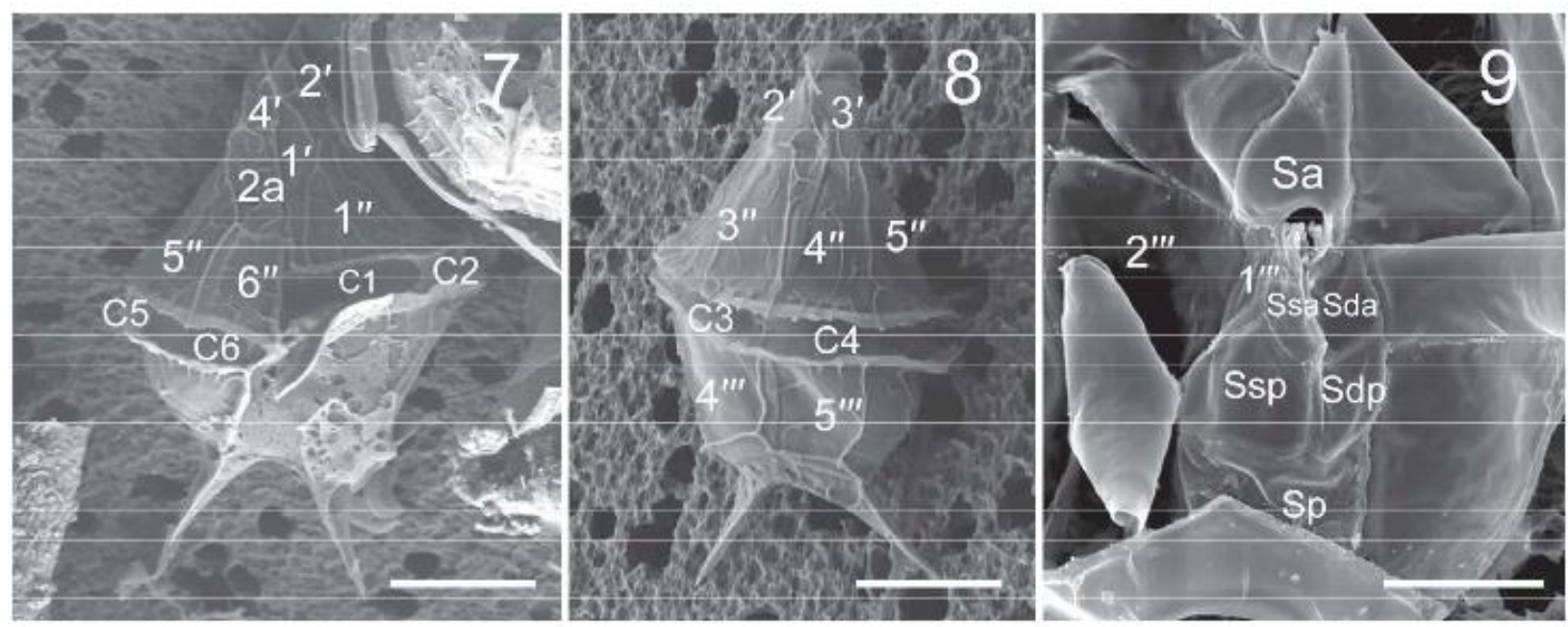

Figs 10-17. Scanning electron micrographs of cells of Sourniaea diacantha ribotype B strain

LIMS-PS-2720 from South Korea.

Fig. 10. Ventral view showing apical plates $\left(1^{\prime}-3^{\prime}\right)$, the second anterior intercalary plate $(2 a)$, and three precingular plates (1", 6", 7"), and three cingular plates (C1, C2, C6). Scale bar $=10 \mu \mathrm{m}$.

Fig. 11. Dorsal view showing four precingular plates $\left(2^{\prime \prime}-5{ }^{\prime \prime}\right)$, two postcingular plates $\left(4^{\prime \prime \prime}, 5^{\prime \prime \prime}\right)$ and four cingular plates (C2-C5). Scale bar $=3 \mu \mathrm{m}$.

Fig. 12. Dorsal apical view showing two apical $\left(2^{\prime}, 3^{\prime}\right)$ and four precingular plates $\left(1^{\prime \prime}-4^{\prime \prime}\right)$. Scale bar $=5 \mu \mathrm{m}$.

Fig. 13. Apical view showing four apical plates, two anterior intercalary plates, and seven precingular plates $\left(1^{\prime \prime}-7^{\prime \prime}\right)$. Scale bar $=5 \mu \mathrm{m}$.

Fig.14. Ventral view showing three apical plates $\left(1^{\prime}, 2^{\prime}\right.$ and $\left.4^{\prime}\right)$ and two anterior intercalary plates.

Scale bar $=1 \mu \mathrm{m}$.

Fig. 15. Dorsal view showing three precingular plates (3", $4^{\prime \prime}$ and $\left.5^{\prime \prime}+6^{\prime \prime}\right)$. Scale bar $=10 \mu \mathrm{m}$.

Fig. 16. Antapical view showing three postcingular plates $\left(4^{\prime \prime \prime}-6^{\prime \prime \prime}\right)$ and antapical plate. Scale bar 
$=5 \mu \mathrm{m}$.

Fig. 17. Ventral view showing sulcal plates, postcingular plates $\left(1^{\prime \prime \prime}-3^{\prime \prime \prime}\right)$ and posterior intercalary plate (1p). Scale bar $=3 \mu \mathrm{m}$.
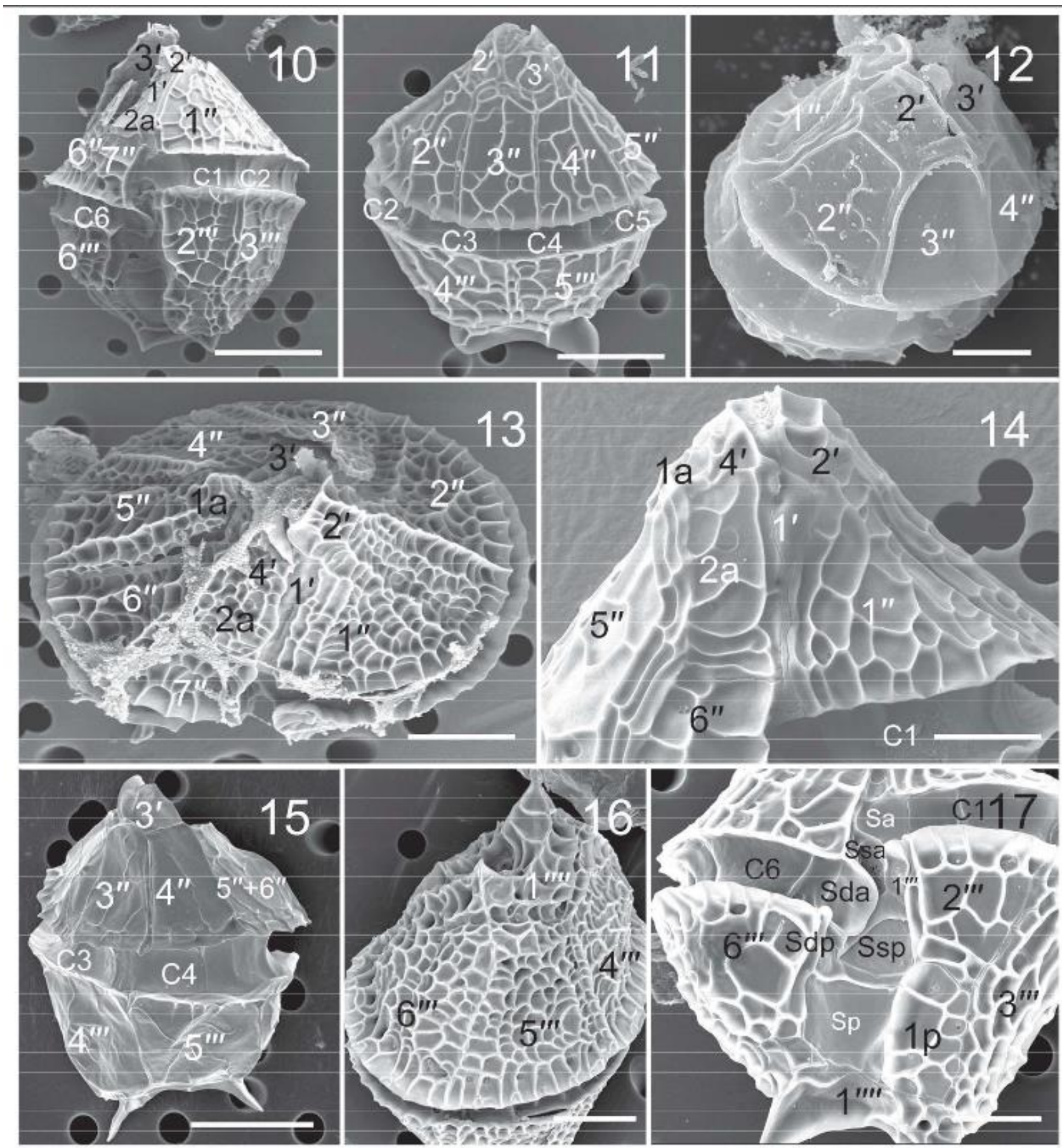

Figs 18-23. Light and scanning electron micrographs of Sourniaea diacantha ribotype A from China and French Atlantic. Scale bars $=5 \mu \mathrm{m}$. 
Figs 18, 19. Ventral view of a cell of Chinese strain G54 showing four apical plates, a small ventral pore (arrow), two anterior intercalary plates and seven precingular plates (LM).

Fig. 20. Ventral view of a cell of Chinese strain G54 showing two curved and unequal antapical spines (SEM).

Fig. 21. Ventral view of a cell of French strain TIO666 showing the first and third apical plates and two anterior intercalary plates (LM).

Fig. 22. Dorsal view of a cell of French strain TIO666 showing five precingular plates (LM).

Fig. 23. A living cyst from French Atlantic (LM).
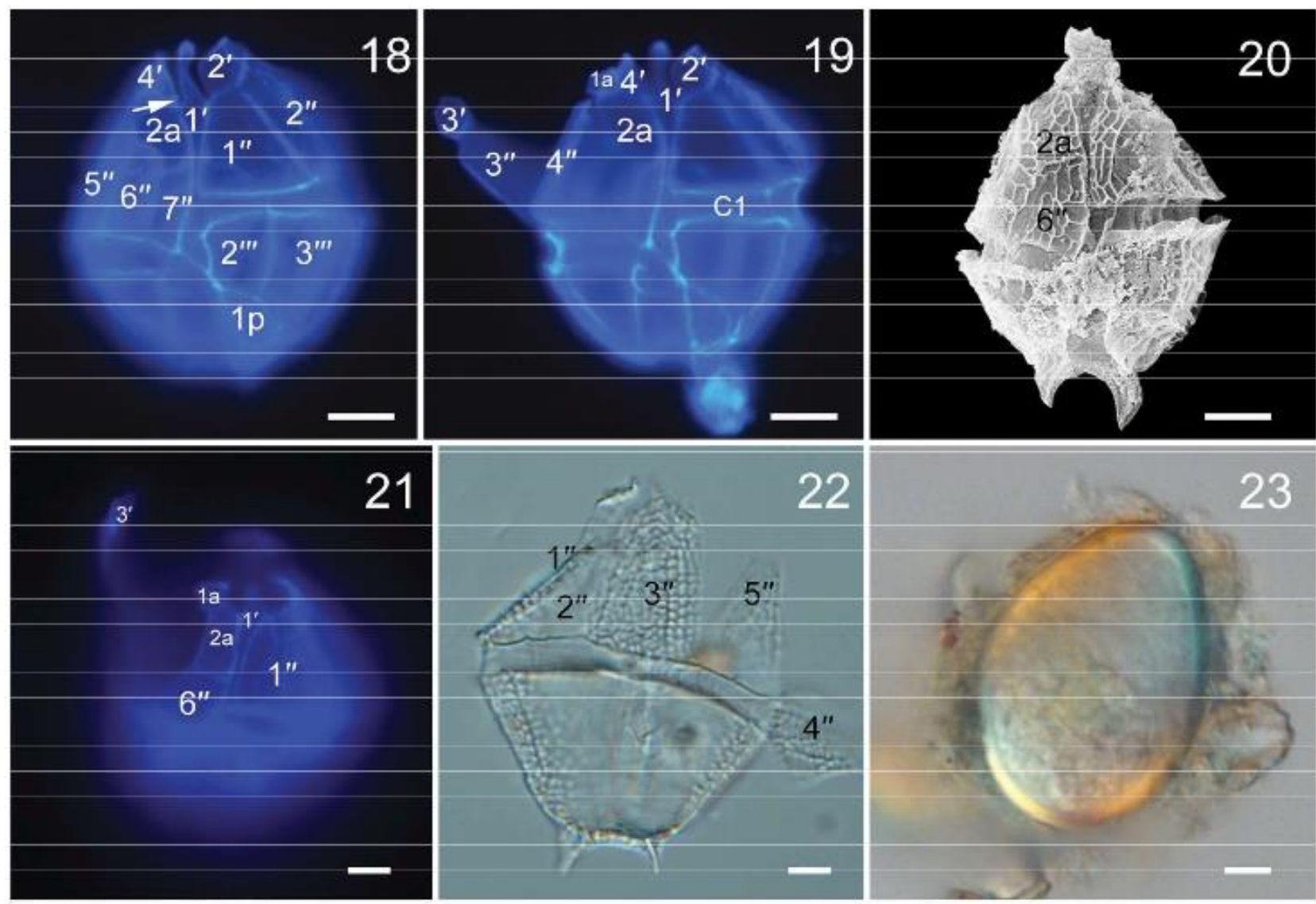

Figs 24-28. Scanning electron micrographs of cells of Sourniaea diacantha ribotype A strain LH11 from the Caspian Sea. 
Fig. 24. Ventral view showing two short antapical spines, the first and sixth cingular plates and postcingular plates $\left(2^{\prime \prime \prime}, 3^{\prime \prime \prime}, 6^{\prime \prime \prime}\right)$. Scale bar $=5 \mu \mathrm{m}$.

Fig. 25. Dorsal view showing three precingular plates $\left(2^{\prime \prime}-4{ }^{\prime \prime}\right)$, two postcingular plates $\left(4^{\prime \prime \prime}, 5^{\prime \prime \prime}\right)$ and three cingular plates $(\mathrm{C} 3-\mathrm{C} 5)$. Scale bar $=5 \mu \mathrm{m}$.

Fig. 26. The sulcal plates and the first postcingular plate. Scale bar $=2 \mu \mathrm{m}$.

Fig. 27. Internal view showing four apical plates, a small ventral pore (arrowhead), two anterior intercalary plates, three precingular plates (1", 5", 6") and three cingular plates (C1-C3). Scale bar $=4 \mu \mathrm{m}$.

Fig. 28. Dorsal view showing two apical plates $\left(2^{\prime}, 3^{\prime}\right)$ and three precingular plates $\left(2^{\prime \prime}-4^{\prime \prime}\right)$.

Scale bar $=1 \mu \mathrm{m}$.
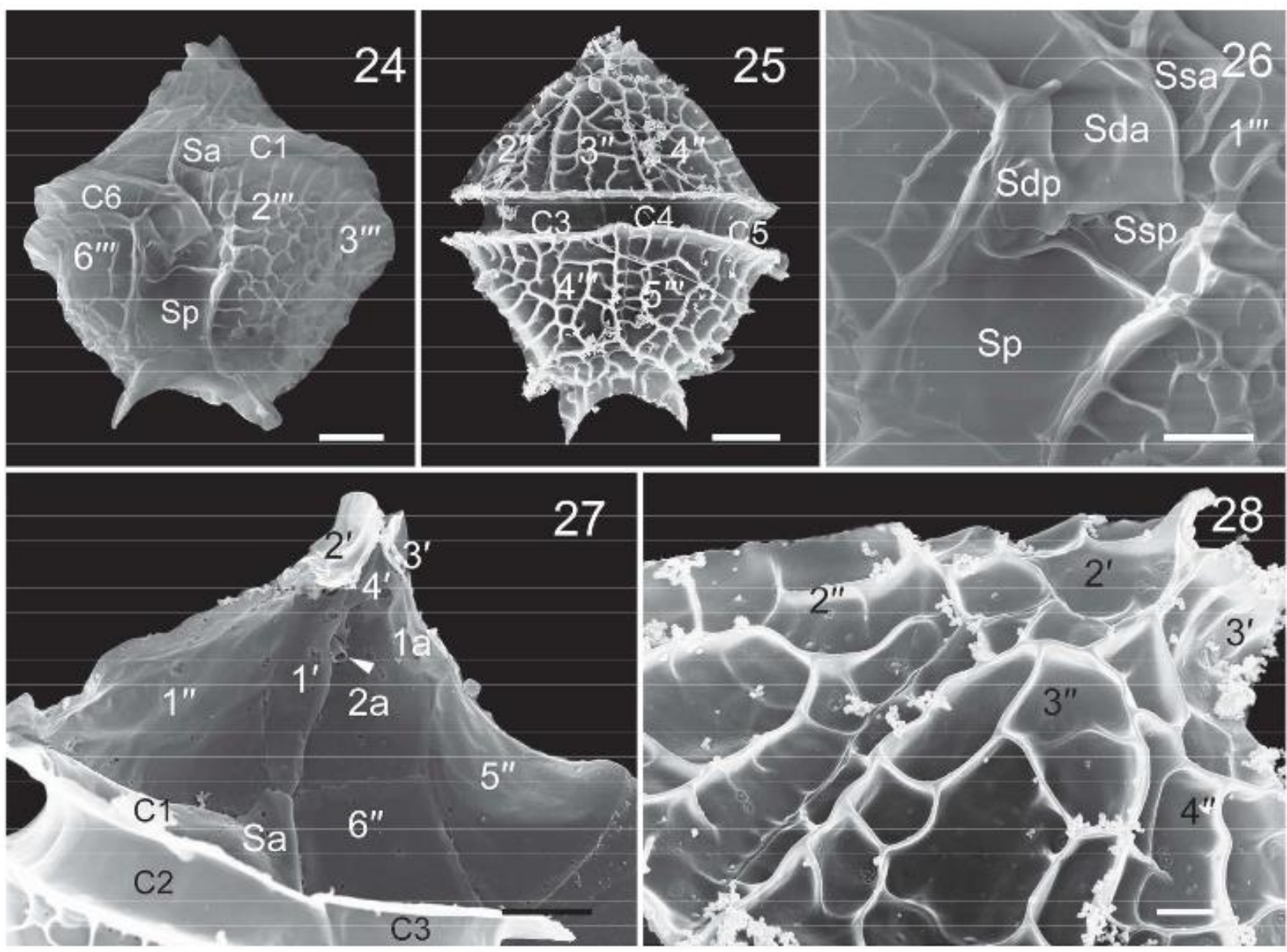

Figs 29-32. Schematic drawings of Sourniaea diacantha. 
Fig. 29. Ventral view.

Fig. 30. Apical view.

Fig. 31. Antapical view.

Fig. 32. Dorsal view.
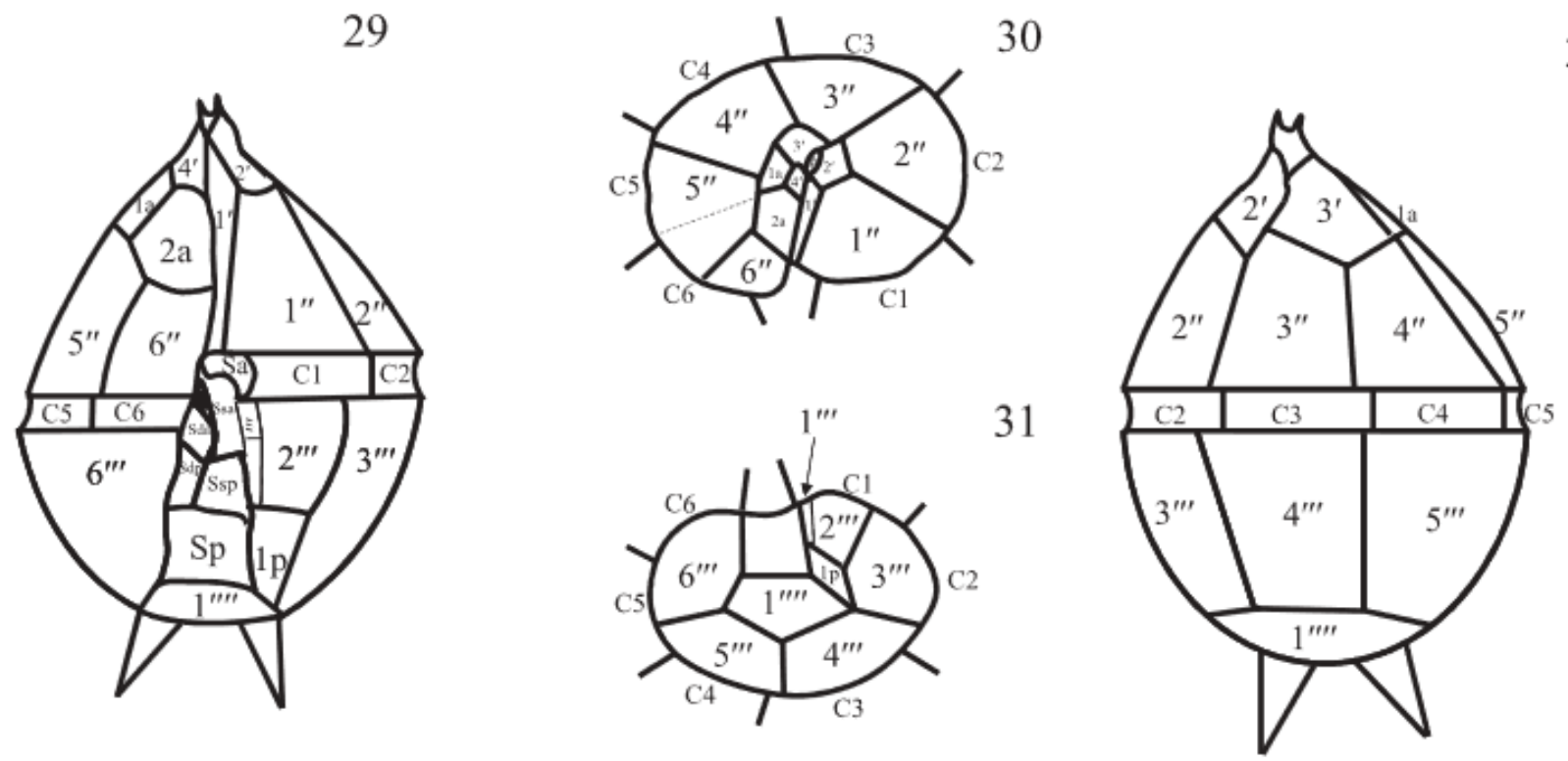

Fig. 33. Phylogeny of Sourniaea diacantha and Pyxidinopsis psilata inferred from partial SSU rRNA gene sequences using maximum likelihood (ML). New sequences indicated in red. Five families labeled and marked with vertical lines on the right. Two ribotypes (A and B) of Sourniaea diacantha labeled and marked with dashed lines. Branch lengths drawn to scale, with scale bar indicating the number of nucleotide substitutions per site. Numbers on branches are statistical support values to clusters on the right of them (left: ML bootstrap support values; right: Bayesian posterior probabilities). Only ML bootstrap support values above 50 and Bayesian posterior probabilities above 0.9 are shown. * indicates maximal support (ML bootstrap support: 100, BI posterior probability: 1.0). 


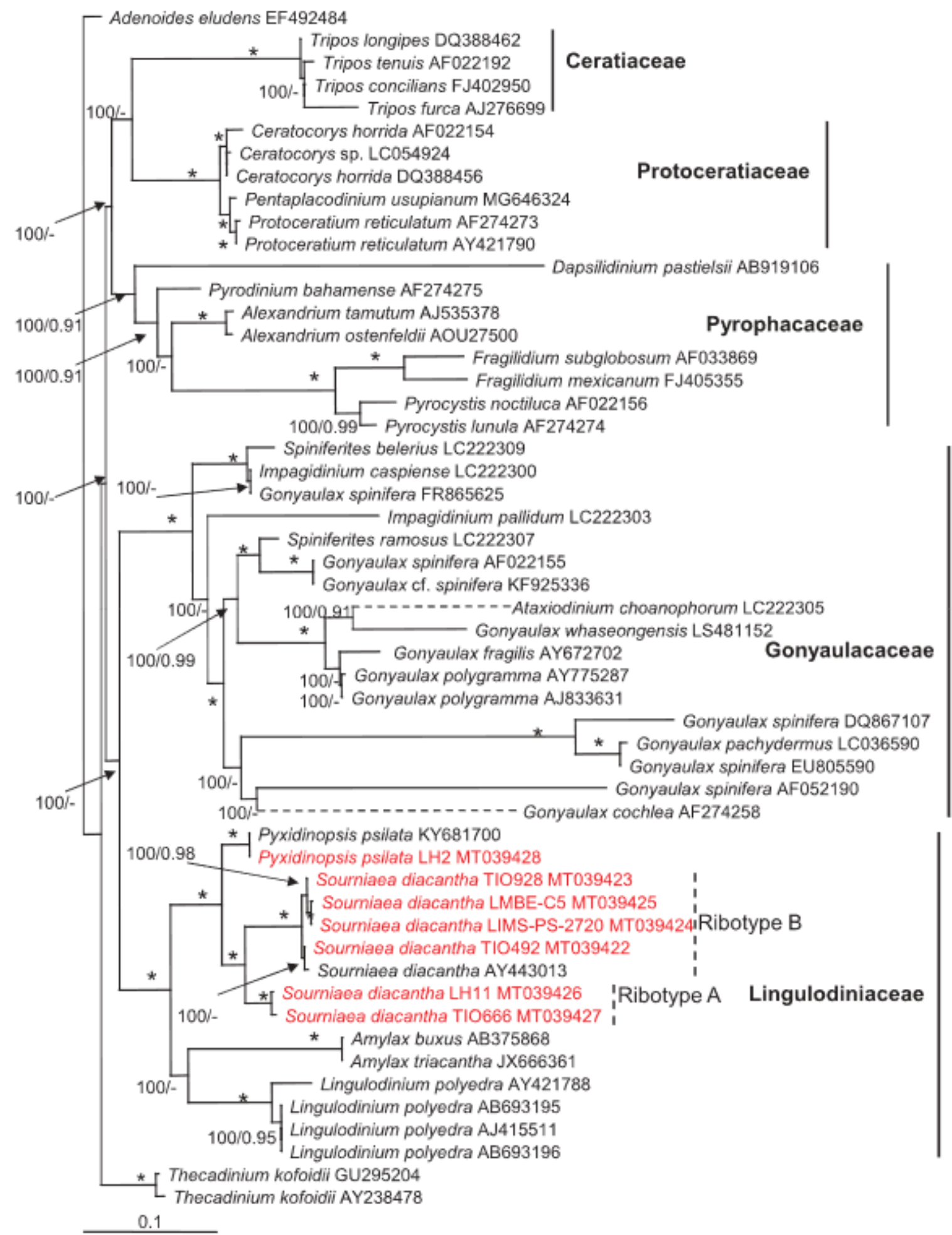

Fig. 34. Phylogeny of Sourniaea diacantha and Pyxidinopsis psilata inferred from partial LSU rRNA

(D1-D6) gene sequences using maximum likelihood (ML). New sequences indicated in red.

Five families labelled and marked with vertical lines on the right. Two ribotypes (A and B) of

Sourniaea diacantha labeled and marked with dashed lines. Branch lengths drawn to scale, 
with scale bar indicating number of nucleotide substitutions per site. Numbers on branches are statistical support values to clusters on the right of them (left: ML bootstrap support values; right: Bayesian posterior probabilities). Only ML bootstrap support values above 50 and Bayesian posterior probabilities above 0.9 are shown. * indicates maximal support (ML bootstrap support: 100, BI posterior probability: 1.0). 


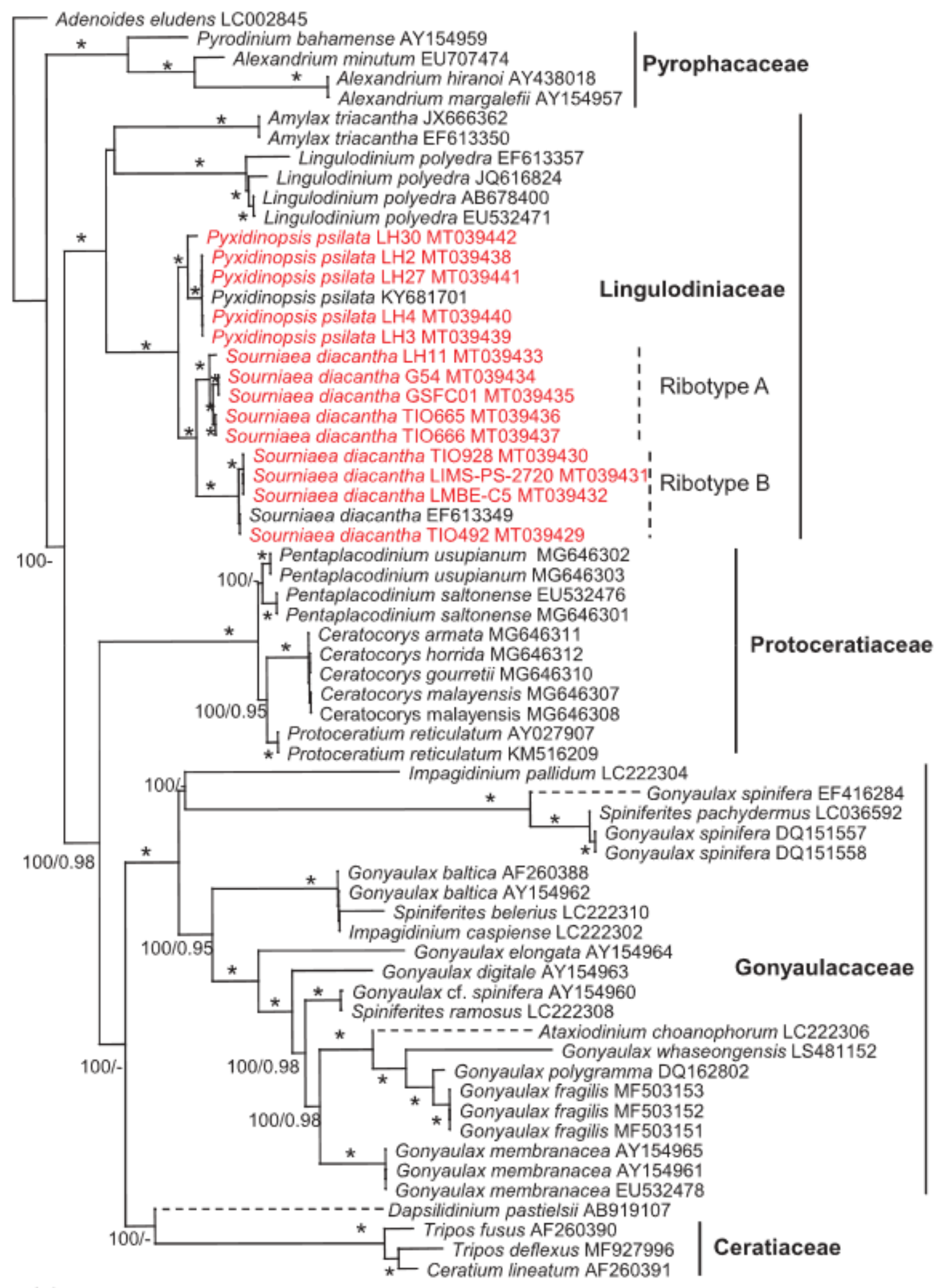


Fig. S1. Map of sampling locations showing the occurrence of Sourniaea diacantha ribotypes A and $\mathrm{B}$.

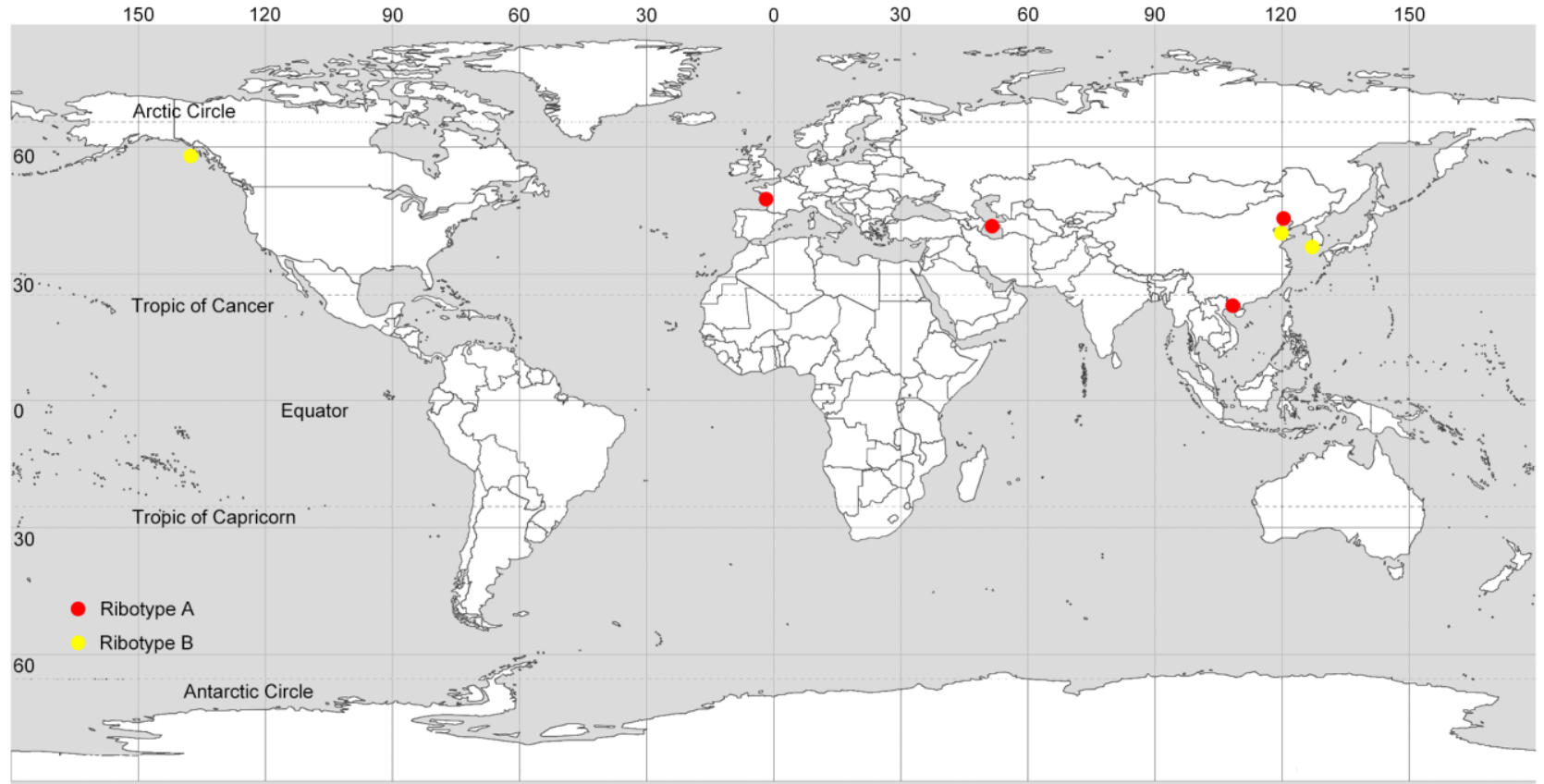


Table 1. Information on Sourniaea and Pyxidinopsis isolates used in this study. Species designation, strain identification, origin, collection date, ribotypes and GeneBank accession numbers.

\begin{tabular}{|c|c|c|c|c|c|c|c|c|}
\hline & Strains/isolates & $\begin{array}{l}\text { Collection } \\
\text { date }\end{array}$ & Latitude & Longitude & Location & Origin & Ribotypes & $\begin{array}{l}\text { GeneBank No. } \\
\text { (SSU/ITS/LSU) }\end{array}$ \\
\hline $\begin{array}{l}S . \\
\text { diacantha }\end{array}$ & TIO492 & 20 Apr. 2017 & $48^{\circ} 25.8^{\prime} \mathrm{N}$ & $123^{\circ} 28.1^{\prime} \mathrm{W}$ & $\begin{array}{l}\text { Esquimalt Lagoon, British } \\
\text { Columbia, Canada }\end{array}$ & Cyst & B & $\begin{array}{l}\text { МT039422/MT041622 } \\
\text { /МT039429 }\end{array}$ \\
\hline $\begin{array}{l}\text { S. } \\
\text { diacantha }\end{array}$ & TIO928 & 19 Apr. 2018 & $39^{\circ} 55.1^{\prime} \mathrm{N}$ & $119^{\circ} 44.8^{\prime} \mathrm{E}$ & $\begin{array}{l}\text { Qinghuangdao, Bohai Sea, } \\
\text { China }\end{array}$ & Cyst & B & $\begin{array}{l}\text { МT039423/MT041623 } \\
\text { /МT039430 }\end{array}$ \\
\hline $\begin{array}{l}S . \\
\text { diacantha }\end{array}$ & LIMS-PS-2720 & 25 Jun. 2018 & $35^{\circ} 21.6^{\prime} \mathrm{N}$ & $129^{\circ} 21.8^{\prime} \mathrm{E}$ & Ulsan, South Korea & Cell & B & $\begin{array}{l}\text { MT039424/MT041624 } \\
\text { /MT039431 }\end{array}$ \\
\hline $\begin{array}{l}S . \\
\text { diacantha }\end{array}$ & LMBE-C5 & 11 Apr. 2013 & $35^{\circ} 4.6^{\prime} \mathrm{N}$ & $128^{\circ} 29.2^{\prime} \mathrm{E}$ & $\begin{array}{l}\text { Jinhae-Masan Bay, South } \\
\text { Korea }\end{array}$ & Cyst & B & $\begin{array}{l}\text { MT039425/MT041625 } \\
\text { /MT039432 }\end{array}$ \\
\hline $\begin{array}{l}S . \\
\text { diacantha }\end{array}$ & LH11 & 9 Mar. 2011 & $37^{\circ} 30.6^{\prime} \mathrm{N}$ & $49^{\circ} 54.6^{\prime} \mathrm{E}$ & SW Caspian Sea, Iran & Cyst & $\mathrm{A}$ & $\begin{array}{l}\text { МT039426/MT041626 } \\
\text { /MT039433 }\end{array}$ \\
\hline
\end{tabular}


$S$.

diacantha

$S$.

diacantha

GSFC01

$S$.

diacantha

$S$.

diacantha

TIO666

P. psilata

LH2

P. psilata

LH3

P. psilata LH4

P. psilata LH27
28 Apr. $2011 \quad 40^{\circ} 43.6^{\prime} \mathrm{N}$

$121^{\circ} 2.5^{\prime} \mathrm{E}$

Jinzhou, Bohai Sea, China

Fangchenggang, South China

22 May $2010 \quad 21^{\circ} 28.5^{\prime} \mathrm{N}$

$108^{\circ} 12.4^{\prime} \mathrm{E}$

Sea, China

Cyst

21 Nov. 2018

$47^{\circ} 52.5^{\prime} \mathrm{N}$

$3^{\circ} 57.3^{\prime} \mathrm{W}$

Concarneau Bay, France

Cyst

A

A

Cyst

21 Nov. $2018 \quad 47^{\circ} 52.5^{\prime} \mathrm{N}$

$3^{\circ} 57.3^{\prime} \mathrm{W}$

Concarneau Bay, France

Cyst

9 Mar. $2011 \quad 37^{\circ} 30.6^{\prime} \mathrm{N}$

$49^{\circ} 54.6^{\prime} \mathrm{E}$

SW Caspian Sea, Iran

NA

/ MT039436

MT039428/MT041628

/MT039438

NA

Cyst

9 Mar. $2011 \quad 37^{\circ} 30.6^{\prime} \mathrm{N} \quad 49^{\circ} 54.6^{\prime} \mathrm{E} \quad$ SW Caspian Sea, Iran

$49^{\circ} 54.6^{\prime} \mathrm{E} \quad$ SW Caspian Sea, Iran

Cyst

NA

Cyst NA

-/-/MT039434

-/-/MT039435

-/-/MT039436

MT039428/MT041627

KY681700/MT041629

/MT039439

-/-/MT039440

9 Mar. $2011 \quad 37^{\circ} 30.6^{\prime} \mathrm{N} \quad 49^{\circ} 54.6^{\prime} \mathrm{E} \quad$ SW Caspian Sea, Iran 
Table 2. Cell size and spine length of Sourniaea diacantha strains. Measurements indicate ranges and mean $\pm \mathrm{s}$.

\begin{tabular}{llllll}
\hline Ribotypes & Strains & Cell length $(\mu \mathrm{m})$ & Cell width $(\mu \mathrm{m})$ & Spine length $(\mu \mathrm{m})$ & $\mathrm{n}$ \\
\hline B & TIO928 & $22.5-33.8(28.2 \pm 4.4)$ & $16.9-30.0(20.9 \pm 3.7)$ & $2.5-4.3(3.0 \pm 3.7)$ & 12 \\
B & LIMS-PS-2720 & $20.0-34.8(27.0 \pm 3.9)$ & $17.5-30.3(24.4 \pm 3.7)$ & $1.8-6.1(3.8 \pm 1.2)$ & 23 \\
B & LMBE-C5 & $23.3-32.2(28.5 \pm 2.6)$ & $18.3-25.8(21.8 \pm 2.2)$ & $5.8-11.1(8.7 \pm 1.8)$ & 13 \\
A & LH11 & $24.6-34.0(28.7 \pm 2.5)$ & $24.0-30.0(26.8 \pm 1.9)$ & $3.4-5.4(4.4 \pm 0.7)$ & 14 \\
A & G54 & $22.0-32.4(27.7 \pm 2.8)$ & $20.0-27.0(23.8 \pm 2.4)$ & $4.7-7.5(6.0 \pm 0.9)$ & 10 \\
A & TIO665 & $35.9-47.9(44.0 \pm 4.4)$ & $27.5-34.7(30.5 \pm 2.5)$ & $4.8-7.2(5.5 \pm 1.0)$ & 9 \\
A & TIO666 & $41.9-50.2(47.1 \pm 3.1)$ & $29.9-37.3(32.7 \pm 2.8)$ & $4.3-7.2(5.4 \pm 1.0)$ \\
\hline
\end{tabular}


Table 3. Pairwise genetic distances based on ITS-5.8S rRNA gene sequences among Lingulodinium, Sourniaea and Pyxidinopsis species.

\begin{tabular}{lllllll}
\hline & AM184208 & TIO928 & TIO492 & TIO666 LH11 LH2 \\
\hline L. polyedra AM184208 & - & & & & \\
S. diacantha TIO928 & 0.78 & - & & & & \\
S. diacantha TIO492 & 0.79 & 0.05 & - & & & \\
S. diacantha TIO666 & 0.82 & 0.34 & 0.32 & - & \\
S. diacantha LH11 & 0.82 & 0.35 & 0.33 & 0.06 & - \\
P. psilata LH2 & 0.89 & 0.41 & 0.41 & 0.31 & 0.34 & - \\
\hline
\end{tabular}


Table 4. Comparisons of families Protoceratiaceae, Gonyaulacaceae and Lingulodiniaceae.

\begin{tabular}{|c|c|c|c|c|}
\hline Families & APC & Sulcus & Ventral pore & Anterior intercalary plates \\
\hline Protoceratiaceae & $\lambda$-shaped & L-type & $\begin{array}{l}\text { Present or absent, } \\
\text { between } 1^{\prime} \text { and } 3^{\prime}\end{array}$ & One \\
\hline Gonyaulacaceae & lancet & S-type & $\begin{array}{l}\text { Present, between } \\
3^{\prime}(=\mathrm{Cv} \text { or } \mathrm{Q}) \\
\text { and } 2 \mathrm{a}\end{array}$ & None or two \\
\hline Lingulodiniaceae & lancet & L-type & $\begin{array}{l}\text { Present or absent, } \\
\text { between } 1^{\prime}, 4^{\prime} \text { (or } \\
5^{\prime} \text { ) and } 2 \mathrm{a}\end{array}$ & None or two and more \\
\hline
\end{tabular}

